\title{
Amplified fragment length polymorphism and multilocus sequence analysis-based genotypic relatedness among pathogenic variants of Xanthomonas citri pv. citri and Xanthomonas campestris pv. bilvae
}

\author{
Lan Bui Thi Ngoc, Christian Vernière, Emmanuel Jouen, Nathalie Ah-You, \\ Pierre Lefeuvre, Frédéric Chiroleu, Lionel Gagnevin and Olivier Pruvost
}

Correspondence Olivier Pruvost olivier.pruvost@cirad.fr
CIRAD, UMR Peuplements Végétaux et Bioagresseurs en Milieu Tropical CIRAD-Université de la Réunion, Pôle de Protection des Plantes, 7 chemin de l'Irat, 97410 Saint Pierre, La Réunion, France

\section{INTRODUCTION}

The classification of some phytopathogenic bacterial species was initially based on host specialization, although this was evidently not sound taxonomically (Dowson, 1939; Stolp et al., 1965). Nevertheless, plant pathologists

\footnotetext{
Abbreviations: AFLP, amplified fragment length polymorphism; EGD, evolutionary genome divergence; ML, maximum-likelihood; MLSA, multilocus sequence analysis; $\mathrm{NJ}$, neighbour-joining.

Details of strains and primers, maximum-likelihood trees based on individual sequences and a neighbour-joining tree based on concatenated sequences are available as supplementary material with the online version of this paper.

The GenBank/EMBL/DDBJ accession numbers for the partial sequences used in the MLSA study are EU015124-EU015156, EU015158-EU015215, EU333904-EU333906 and FJ376085FJ376134 (atpD), EU015216-EU015248, EU015250-EU015307, EU333907-EU333909 and FJ376135-FJ376184 (dnaK), FJ376235FJ376379 (efp) and EU015308-EU015340, EU015342-EU015399, EU333910-EU333912 and FJ376185-FJ376234 (gyrB).
}

and phytosanitary policy regulators required names for plant-pathogenic bacteria that clearly reflected their pathogenic ability. This led to the development of the pathovar classification at an infrasubspecific level (Dye et al., 1980). Furthermore, strains with differential host ranges within a pathovar were sometimes described (e.g. xanthomonads pathogenic to citrus or cassava) and often referred to as pathotypes (Civerolo \& Fan, 1982; Verdier et al., 1998).

A total of four xanthomonads are pathogenic to plant species within the Rutaceae. Two pathogens that cause spot diseases of citrus (i.e. water-soaked spots turning into flat, necrotic lesions) have been described as two distinct Xanthomonas pathovars, namely Xanthomonas axonopodis pv. citrumelo (Vauterin et al., 1995) (synonyms Xanthomonas alfalfae pv. citrumelo and Xanthomonas campestris pv. citri pathotype E), the causal agent of citrus bacterial spot, and X. campestris pv. bilvae, a pathogen that causes spots on rutaceous plants in India (Patel et al., 1953), which was not 
reclassified by Vauterin et al. (1995) or in more recent studies. In addition, two pathogens that cause canker-like diseases of citrus have also been described as distinct pathovars. All bacterial pathogens that cause canker-like diseases of citrus are regarded as quarantine organisms in many countries, and high-cost, drastic control measures are often implemented. Xanthomonas citri pv. citri (synonyms $X$. axonopodis pv. citri and $X$. campestris pv. citri pathotype A) is the causal agent of Asiatic canker (Ah-You et al., 2009; Schaad et al., 2006). This pathogen induces erumpent, callus-like lesions with a water-soaked margin on leaf, fruit and stem tissue. Severe attacks cause extensive defoliation, premature fruit drop and twig dieback. The hypothesis has been proposed that citrus canker originated in India (in the 1830s) or Java (in the 1840s), rather than other regions, because the oldest herbarium specimens with canker lesions originated from these areas (Fawcett \& Jenkins, 1933). Citrus canker now occurs in more than 30 countries throughout the world, including in Africa, where it is currently re-emerging (Balestra et al., 2008; Traoré et al., 2008). Its presence in many areas is a continuous threat to citriculture (Civerolo, 1984). This pathogen is of major concern because of its wide host range among citrus and related species, extreme aggressiveness and widespread distribution worldwide (Gottwald et al., 2002). Strains of this pathogen will be referred to as pathotype A strains hereafter. X. citri pv. aurantifolii (synonyms Xanthomonas fuscans pv. aurantifolii, X. axonopodis pv. aurantifolii and $X$. campestris pv. citri pathotypes B and C) is responsible for the milder, geographically restricted South American canker, pathogenic to a narrower host range, including lemons and limes, which are the most susceptible species (Ah-You et al., 2009; Schaad et al., 2006). In comparison with X. citri pv. citri, $X$. citri pv. aurantifolii has a lower economic incidence on citrus production. These two pathogens are phenotypically and genetically distinct (Hartung \& Civerolo, 1989; Pruvost et al., 1992; Rademaker et al., 2005; Vernière et al., 1993). More recently, xanthomonads with a narrow host range but shown to be genetically related to $X$. citri pv. citri using RFLP analysis were reported from different areas of south-west and central Asia, including Saudi Arabia, Oman, Iran, India, Thailand and Cambodia (Bui Thi Ngoc et al., 2007, 2008; Vernière et al., 1998). These strains, designated pathotype $A^{\star}$, all originated from Mexican lime (Citrus aurantifolia) and produced canker-like lesions on this host species after inoculation, but not on grapefruit (Citrus paradisi), a species highly susceptible to $X$. citri pv. citri (Vernière et al., 1998). Finally, strains naturally pathogenic to Mexican lime and alemow (Citrus macrophylla) were detected in Florida and designated pathotype $\mathrm{A}^{\mathrm{w}}$ (Sun et al., 2004). These strains did not produce an amplicon when assayed using specific primers designed for pathotype A strains (Hartung et al., 1993; Sun et al., 2004). Recent DNADNA hybridization data suggested that pathotype $\mathrm{A}^{*}$ and $\mathrm{A}^{\mathrm{w}}$ strains should be classified within the $X$. citri genospecies (Sun et al., 2004). However, no large collection of strains has been studied using high-throughput techniques, as recommended by Stackebrandt et al. (2002).
Amplified fragment length polymorphism (AFLP) and multilocus sequence analysis (MLSA) are used here to gain insight into phylogenetic relatedness among $X$. citri pv. citri strains and relatives. AFLP (Vos et al., 1995) is based on arbitrary genome sampling and generates large numbers of markers over the whole genome. AFLP has proven useful for resolving the species status of several xanthomonads (Ah-You et al., 2009; Janssen et al., 1996; Rademaker et al., 2000; Roumagnac et al., 2004), especially after calculating evolutionary genome divergence (EGD) between individuals. EGD estimates the number of nucleotide substitutions that have occurred since the strains diverged from a common ancestor, and is well correlated with other evolutionary indicators (Mougel et al., 2002). Recently, MLSA, based on sequence analysis of several housekeeping genes, has been developed for species delineation (Chelo et al., 2007; Gevers et al., 2005; Hanage et al., 2005a, b; Martens et al., 2007; Richter et al., 2006), including members of Xanthomonas. The advantage of MLSA is that phylogenetic relationships of large sets of strains can be analysed with a better portability than for genotyping techniques such as AFLP or rep-PCR.

We have established previously (Ah-You et al., 2009) that AFLP and MLSA based on atpD (encoding the F1-F0 ATPase $\beta$ subunit), dnaK (70 $\mathrm{kDa}$ heat-shock protein, Hsp70) and gyrB (DNA gyrase subunit $\beta$ ) sequences have the potential to discriminate among Xanthomonas species, and the latter study yielded a redefinition of Xanthomonas citri. The present study is a follow-up that aimed to complement our MLSA scheme with an additional partial gene sequence, efp (encoding elongation factor $\mathrm{P}$ ), and to evaluate the pathological and phylogenetic relatedness to different Xanthomonas species and pathovars of a large set of strains pathogenic to rutaceous host species (including the unreclassified citrus pathogen X. campestris pv. bilvae).

\section{METHODS}

Bacterial strains and DNA extraction. Bacterial strains used in this study are listed in Supplementary Table S1, available in IJSEM Online. Cultures were stored as lyophiles and/or at $-80{ }^{\circ} \mathrm{C}$ in microbank tubes (Fisher Scientific). Cultures were obtained on YPGA $\left(1^{-1}: 7 \mathrm{~g}\right.$ yeast extract, $7 \mathrm{~g}$ peptone, $7 \mathrm{~g}$ glucose, $18 \mathrm{~g}$ agar, $20 \mathrm{mg}$ propiconazole, $\mathrm{pH} 7.2$ ), incubated at $28{ }^{\circ} \mathrm{C}$ for $3-8$ days. Single colonies were subcultured on YPGA for $24 \mathrm{~h}$ at $28{ }^{\circ} \mathrm{C}$. These subcultures were used to inoculate $4 \mathrm{ml} \mathrm{YP}$ broth tubes, which were incubated at $28{ }^{\circ} \mathrm{C}$ under agitation for 16-18 h. These suspensions were used for DNA extraction using the DNeasy tissue kit (Qiagen) following the manufacturer's instructions and DNA concentrations were estimated by fluorimetry (TKO 100 fluorimeter; Hoefer).

Pathogenicity tests. Strains submitted to pathogenicity tests are shown in Supplementary Table S1. They included strains of pathovars aurantifolii and bilvae and pathogenicity variants of pathovar citri (i.e. pathotypes $\mathrm{A}, \mathrm{A}^{*}$ and $\mathrm{A}^{\mathrm{w}}$ ). Inoculations, as described previously (Vernière et al., 1998), were performed on five Citrus species: $C$. sinensis (pineapple sweet orange), C. aurantifolia (Mexican lime), C. macrophylla (alemow), C. latifolia (Tahiti lime) and C. paradisi (Marsh grapefruit). Immature fully expanded citrus leaves were sterilized by soaking for 2 min in $1 \%$ sodium hypochlorite and rinsed three times in sterile distilled water. 
Leaves were placed on the surface of $1 \%$ water agar plates with adaxial surfaces facing upwards. Ten wounds per leaf were made with a sterile needle and droplets $(5 \mu \mathrm{l})$ of bacterial suspensions containing approximately $1 \times 10^{6}$ c.f.u. $\mathrm{ml}^{-1}$ were placed on each wound. Bacterial suspensions used for inoculation were prepared in $0.01 \mathrm{M}$ sterile Sigma 7-9 Tris buffer ( $\mathrm{pH}$ 7.2) (Sigma-Aldrich) and obtained by tenfold dilutions of spectrophotometrically adjusted suspensions (an $\mathrm{OD}_{600}$ of 0.05 is approximately equivalent to $10^{8}$ c.f.u. $\mathrm{ml}^{-1}$ ) prepared from $18 \mathrm{~h}$ old cultures on YPGA. Sterile Tris buffer was used as inoculum for negative controls. Leaves were incubated in a growth chamber at $28{ }^{\circ} \mathrm{C}$ with a photoperiod of $12 \mathrm{~h}$ and observed for the development of tissue hyperplasia after 7-21 days. For pv. bilvae strains, attached leaves of $C$. sinensis, C. aurantifolia, C. macrophylla and C. paradisi were inoculated by infiltration of bacterial suspensions containing approximately $1 \times 10^{5}$ c.f.u. $\mathrm{ml}^{-1}$ as described previously (Ah-You et al., 2007). Leaves were checked daily for lesion development over 3 weeks and population sizes were determined 1 month after inoculation on KC semi-selective medium as described previously (Ah-You et al., 2007).

In planta population sizes were also determined on 1-year-old potted Marsh grapefruit and alemow plants that were pruned to produce uniformly aged shoots. Nine strains were used for inoculation (Supplementary Table S1). The strain collection consisted of four $\mathrm{A}^{\star}$ strains (originating from Iran, Pakistan, Saudi Arabia and Thailand), one $\mathrm{A}^{\mathrm{w}}$ strain (from Florida) and four A strains (from Bangladesh, New Zealand, Pakistan and the Philippines). Bacterial suspensions used for inoculation contained approximately $1 \times 10^{5}$ c.f.u. $\mathrm{ml}^{-1}$ and were prepared as explained above. Suspensions were infiltrated $(0.4-$ $0.5 \mathrm{~cm}^{2}$ ) into the mesophyll of mature leaves from the youngest vegetative flush using a sterile syringe. For each strain, 10 inoculation points were performed on each of 12 leaves on different plants. Each experiment was replicated once. Plants were placed in growth chambers at $30 \pm 1{ }^{\circ} \mathrm{C}$ day and $26 \pm 1{ }^{\circ} \mathrm{C}$ night and $95 \pm 5 \%$ relative humidity for 35 days with a photoperiod of $12 \mathrm{~h}$. Inoculated leaf fragments were sampled $1,2,5,8,12,20,28$ and 35 days postinoculation (p.i.). At each sampling time, ten leaf discs (about $1 \mathrm{~cm}^{2}$ ) per strain and per host species were homogenized in $5 \mathrm{ml} 0.01 \mathrm{M}$ sterile Sigma 7-9 Tris buffer ( $\mathrm{pH}$ 7.2) (Sigma-Aldrich) using an Ultraturax T25 homogenizer (Janke \& Kunkel). Aliquots of the homogenized suspensions and of the tenfold dilutions obtained from the suspensions were plated on KC semi-selective medium (Pruvost $e t$ al., 2005) using the Spiral System device (Interscience). Bacterial population sizes were based on enumeration of Xanthomonas-like colonies (starch hydrolysis was checked on doubtful colonies). Data were analysed by ANOVA using $\mathrm{R}$ software (version 2.6.1; $\mathrm{R}$ Development Core team). Whenever $\mathrm{F}$ values were significant $(P<0.05)$, Tukey's contrasts were used to differentiate amongst the means of the population sizes at a level of 0.05 .

PCR assay. A specific nested-PCR assay for X. citri pv. citri was performed using previously developed primers (Hartung et al., 1993, 1996). The assayed strains included all pathotype $A^{\star}$ and $A^{\mathrm{w}}$ strains, in addition to LMG 9322 and CFBP 2525 reference A strains. Genomic DNA and X. citri pv. citri suspensions in sterile HPLC-grade water that were boiled for $1 \mathrm{~min}$ and then cooled on ice were used as templates for PCR. All tests were performed with a GeneAmp PCR system 9700 thermocycler (Applied Biosystems). The first round of PCR was performed with primers 4 ( $5^{\prime}$-TGTCGTCGCTTGTATGGC$\left.3^{\prime}\right)$ and 7 (5'-AGGGTGCGACCGTTCAGGA-3'), which produced a $468 \mathrm{nt}$ fragment for pathotype A strains. The amplification program consisted of 35 cycles of denaturation at $95{ }^{\circ} \mathrm{C}$ for $70 \mathrm{~s}$, annealing at $58{ }^{\circ} \mathrm{C}$ for $1 \mathrm{~min}$ and extension at $72{ }^{\circ} \mathrm{C}$ for $1 \mathrm{~min}$. The primers used in the second PCR round were 94-3 (5'-CTCGATCACGATGTCCTTCTCC-3') and 94-4 (5'-GTGGATGGCATGAGCATGAAG-3'), which yielded a $315 \mathrm{nt}$ fragment for pathotype A strains. For this second round of PCR, $1 \mu \mathrm{l}$ from the first reaction was used as a template. The amplification program consisted of 20 cycles of denaturation at $95{ }^{\circ} \mathrm{C}$ for $70 \mathrm{~s}$, annealing at $58{ }^{\circ} \mathrm{C}$ for $1 \mathrm{~min}$ and extension at $72{ }^{\circ} \mathrm{C}$ for $1 \mathrm{~min}$. PCRs were performed in $25 \mu \mathrm{l}$ reaction mixtures containing $3 \mathrm{mM} \mathrm{MgCl} 2,125 \mu \mathrm{M}$ of each dNTP, $0.5 \mu \mathrm{M}$ of each primer, $1 \mu \mathrm{l}$ template DNA and $1.25 \mathrm{U}$ Goldstar Red Taq polymerase (Eurogentec) in $75 \mathrm{mM} \mathrm{Tris} / \mathrm{HCl}, 20 \mathrm{mM}\left(\mathrm{NH}_{4}\right)_{2} \mathrm{SO}_{4}$, $0.01 \%$ Tween 20 buffer ( $\mathrm{pH} 8.8$ ). PCR products were separated by electrophoresis in $1.5 \%$ Seakem LE agarose (FMC Bioproducts), stained with ethidium bromide and visualized with UV light. The amplicons produced from the second round of PCR from two strains (NCPPB 3608 and X2002-1035G) for which no signal was observed after the first PCR round were sequenced (Macrogen).

AFLP analysis. The experiments were performed in 96-well plates in a GeneAmp PCR system 9700 thermocycler (Applied Biosystems), as described previously (Ah-You et al., 2007). Digestions were carried out in a $25 \mu \mathrm{l}$ volume for $1 \mathrm{~h}$ at $37^{\circ} \mathrm{C}$ and contained $100 \mathrm{ng}$ bacterial genomic DNA, $10 \mathrm{U}$ SacI, $2 \mathrm{U}$ MspI (New England Biolabs) and $1 \times$ BSA in $1 \times$ reaction buffer NEB 1 . Next, an aliquot of $2.5 \mu$ of the digested products was added to $22.5 \mu$ l ligation mixture containing $2 \mu \mathrm{M} \mathrm{MspI}$ adaptor (Supplementary Table S2), $0.2 \mu \mathrm{M}$ SacI adaptor (Supplementary Table S2) (Applied Biosystems), and 2 U T4 DNA ligase (New England Biolabs) in $1 \times$ T4 DNA ligation buffer. Ligations were performed for $3 \mathrm{~h}$ at $37{ }^{\circ} \mathrm{C}$ before enzyme inactivation at $65{ }^{\circ} \mathrm{C}$ for $10 \mathrm{~min}$. Ligation products were diluted tenfold with HPLC-grade water before preselective PCR. The reactions were carried out in $15 \mu \mathrm{l}$ and contained $5 \mu \mathrm{l}$ diluted ligation product, $2.5 \mathrm{mM} \mathrm{MgCl}_{2}, 0.23 \mu \mathrm{M}$ each of MspI and SacI primers (Supplementary Table S2), $0.45 \mathrm{mM}$ of each dNTP (New England Biolabs) and 0.5 U Goldstar Red Taq DNA polymerase (Eurogentec) in $1 \times$ Goldstar buffer. The following PCR conditions were used: initial extension to ligate the second strand of the adaptors at $72{ }^{\circ} \mathrm{C}$ for $2 \mathrm{~min}$, a denaturation step at $94{ }^{\circ} \mathrm{C}$ for $2 \mathrm{~min}, 25$ cycles of $94{ }^{\circ} \mathrm{C}$ for $30 \mathrm{~s}, 56{ }^{\circ} \mathrm{C}$ for $30 \mathrm{~s}$ and $72{ }^{\circ} \mathrm{C}$ for $2 \mathrm{~min}$, followed by a final extension step at $72{ }^{\circ} \mathrm{C}$ for $10 \mathrm{~min}$. PCR products were diluted tenfold with HPLC-grade water before selective amplification. Selective amplifications using the unlabelled $M s p \mathrm{I}+\mathrm{A}, \mathrm{C}, \mathrm{T}$ or G primer and the labelled SacI + C primer (four different fluorochromes) (Supplementary Table S2) were performed under the same conditions as the preselective PCR, except that the SacI $+\mathrm{C}$ primer concentration was $0.12 \mu \mathrm{M}$. The following PCR conditions were used: initial denaturation at $94{ }^{\circ} \mathrm{C}$ for 2 min followed by 37 cycles of $94{ }^{\circ} \mathrm{C}$ for $30 \mathrm{~s}$, annealing for $30 \mathrm{~s}$ at $65{ }^{\circ} \mathrm{C}$ for the first cycle, decreased by $0.7{ }^{\circ} \mathrm{C}$ per cycle for the next 12 cycles and then $56{ }^{\circ} \mathrm{C}$ for the last 24 cycles followed by extension at $72{ }^{\circ} \mathrm{C}$ for 2 min with a final extension step at $72{ }^{\circ} \mathrm{C}$ for $10 \mathrm{~min}$. Samples were then prepared for capillary electrophoresis by adding $1 \mu \mathrm{l}$ of the final PCR product to $18.7 \mu \mathrm{l}$ formamide and 0.3 $\mu$ LIZ500 DNA ladder (Applied Biosystems) as an internal standard. The mixture was then denatured for 5 min at $95{ }^{\circ} \mathrm{C}$ and placed on ice for at least $5 \mathrm{~min}$. Electrophoresis was performed in an ABI PRISM 3100 Genetic Analyzer (Applied Biosystems) using performance-optimized polymer POP-4 at $15000 \mathrm{~V}$ for about $20 \mathrm{~min}$ at $60{ }^{\circ} \mathrm{C}$, with an initial injection of $66 \mathrm{~s}$. AFLP fingerprints were analysed visually using GENESCAN software 3.7 (Applied Biosystems). To test the reproducibility of the AFLP technique, two independent DNA extractions were used for all strains. Strain 306 of X. citri pv. citri (Da Silva et al., 2002) was used as a control in each experiment.

Amplified fragments were scored as present (1) or absent (0) to create binary matrices, before analysis using $\mathrm{R}$ software (version 2.6.1; $\mathrm{R}$ Development Core team). Only bands with an intensity above a preset level (500 relative fluorescence units) were scored. EGD values were calculated from the Dice similarity index and corrected to account for unobserved substitutions by using the standard Jukes-Cantor model, which assumes equal rates of nucleotide substitution between all pairs of bases (Mougel et al., 2002). EGD values were used as distances to construct a weighted neighbour-joining $(\mathrm{NJ})$ tree (Paradis et al., 2004) using $R$ software. The robustness of the tree was assessed by bootstrap (1000 resamplings). 
MLSA. Four loci, atpD, dnaK, efp and gyrB (Ah-You et al., 2009; Boudon et al., 2005), were used for analysis (Table 1). All loci were amplified using the BD advantage 2 polymerase mix kit (Clontech), as recommended by the manufacturer, using primers shown in Supplementary Table S3. Amplifications were performed in a PE9600 thermocyler (Applied Biosytems) as follows: an initial denaturation at $95{ }^{\circ} \mathrm{C}$ for 3 min was followed by 35 cycles of denaturation for $1 \mathrm{~min}$ at $95{ }^{\circ} \mathrm{C}$, annealing for $1 \mathrm{~min}$ at $66^{\circ} \mathrm{C}$ and extension for $1 \mathrm{~min}$ at $68{ }^{\circ} \mathrm{C}$ and a final extension step at $68{ }^{\circ} \mathrm{C}$ for $7 \mathrm{~min}$. For a small number of strain-gene combinations, the annealing temperature was modified $\left(63-68{ }^{\circ} \mathrm{C}\right)$ for optimal PCR quality or yield. The amplicons were sequenced by Macrogen or Genome Express (efp) (single-pass doublestranded analysis), using primers shown in Supplementary Table S3. The dnaK, atpD, gyrB and efp sequences from Stenotrophomonas maltophilia K279a were used as the outgroup.

Phylogenetic analyses of housekeeping genes. Alignments were generated using the CLUSTAL_X subalignment tool (Thompson et al., 1997), available in MEGA 4.1 (Tamura et al., 2007). Tajima's D test of selective neutrality (Tajima, 1989) and evaluation of synonymous/ non-synonymous substitution ratios $(\mathrm{Ka} / \mathrm{Ks})$ by the method of Nei \& Gojobori (1986) were calculated using DnaSP version 4.20 (Rozas et al., 2003). Nucleotide identities and translation/transversion ratios were evaluated using Kimura's two-parameter method (Kimura, 1980) with the MEGA 4.1 program (Tamura et al., 2007).

Alignments were screened for evidence of recombination, identification of likely parental sequences and localization of possible recombination breakpoints by using a set of seven non-parametric detection programs: RDP (Martin \& Rybicki, 2000), Geneconv (Padidam et al., 1999), MaxChi (Maynard-Smith, 1992), Chimera (Posada \& Crandall, 2001), bootscan (Martin et al., 2005a), SiScan (Gibbs et al., 2000) and 3Seq (Boni et al., 2007). The programs are implemented in the RDP3 program (Martin et al., 2005b). The analysis was performed with default settings for the different detection methods and the Bonferroni-corrected $P$-value cut-off was set at 0.05 . Recombination events were accepted when detected with three detection methods or more. Breakpoint positions and recombinant sequences inferred for every detected potential recombination event were checked manually and adjusted where necessary using the extensive phylogenetic and recombination signal analysis features available in RDP3 version beta 15 .

Maximum-likelihood (ML) methods were used to infer phylogenetic relationships for each single gene and concatenated genes. The appropriate model of evolution for each dataset was estimated using MODELTEST 3.8 (Posada, 2006) based on the Akaike information criterion (Posada \& Buckley, 2004). The GTR $+\Gamma+\mathrm{I}$ model was selected for $a t p D, d n a K, g y r B$ and the concatenated gene dataset, while the TIM $+\Gamma+\mathrm{I}$ model was selected for $e f p$. Distance matrices derived from each single-gene and concatenated dataset, taking into account the selected model of evolution, were generated in PAUP ${ }^{*}$ version 4.0b10. Correlations between distance matrices derived from AFLP and MLSA using concatenated sequences were tested pairwise using the Mantel test (Mantel, 1967). All Mantel tests were performed using GenAlEx version 6.1 with 9999 permutations (Peakall \& Smouse, 2006).

ML trees, including bootstrap analyses (1000 resamplings), were performed with PhyML software (Guindon \& Gascuel, 2003). NJ trees were constructed using PAUP ${ }^{*}$ version $4.0 \mathrm{~b} 10$ with 1000 replications. Bayesian maximum-likelihood inference was used to reconstruct phylogenies based on the concatenated data using MrBayes version 3.1.1 (Ronquist \& Huelsenbeck, 2003). This program implements the Markov chain Monte Carlo (MCMC) algorithm to approximate the posterior probability distribution of a large number of trees. Two runs with four Markov chains were run simultaneously for $5.0 \times 10^{6}$ generations and sampled every 100 generations. Variations in the ML scores were examined graphically using the Tracer software (http:// tree.bio.ed.ac.uk/software/tracer/). Trees generated prior to stabilization of ML scores were discarded (burn-in of $10 \%$ ). The lambda exponential rate parameter for the branch-length prior was calculated as proposed recently (Brown et al., 2009) using the average branch length of the ML tree derived from the GTR $+\Gamma+\mathrm{I}$ model based on the concatenated dataset, and was used in the Bayesian analysis to eliminate inference of biased branch lengths that occur in Bayesian analysis (Brown et al., 2009).

The Shimodaira-Hasegawa (S-H) test (Shimodaira \& Hasegawa, 1999) was used to determine whether the tree topologies based on each locus fall within the same confidence limits. The significance of differences in the likelihood scores was assessed using a bootstrap test with 1000 replications. This analysis was performed with PAUP* version $4.0 \mathrm{~b} 10$. The $\mathrm{S}-\mathrm{H}$ test was also used to compare tree topologies (NJ, ML and Bayesian methods) based on concatenated data.

The molecular clock hypothesis was tested using Tree-puzzle (Schmidt et al., 2002). ML trees were constructed for each or all codon positions using the quartet puzzling algorithm with and without enforcing the molecular clock. Trees were constructed for each gene using optimized parameters determined previously by MODELTEST. Likelihood ratio tests $(P=0.05)$ were used to compare trees constructed with and without enforcing the molecular clock. When the molecular clock hypothesis was rejected, the same analysis was performed taking each codon position separately. Mean distances between alleles at synonymous $\left(\mathrm{D}_{\mathrm{S}}\right)$ and non-synonymous $\left(\mathrm{D}_{\mathrm{N}}\right)$ sites were calculated using concatenated data after Jukes-Cantor correction by using MEGA 4.1 (Tamura et al., 2007).

Table 1. Results of the S-H test of alternative tree topologies for the genes used for MLSA

${ }^{* *}, P<0.01 ;{ }^{* * *}, P<0.001$. The lowest (best) likelihood scores are indicated in bold.

\begin{tabular}{|c|c|c|c|c|c|}
\hline \multirow[t]{2}{*}{ Tree topology } & \multicolumn{5}{|c|}{ Likelihood scores $(-\ln \mathrm{L})$ for the following datasets } \\
\hline & $a t p D$ & $\operatorname{dnaK}$ & efp & gyrB & Concatenated \\
\hline $\operatorname{atpD}$ & 2479 & $2667^{\star * *}$ & $1491^{\star *}$ & $3278^{* * *}$ & $10230^{* *}$ \\
\hline$d n a K$ & $2949^{* * *}$ & 2439 & $1417^{\star \star}$ & $3207^{\star * *}$ & $10347^{\star \star *}$ \\
\hline efp & $3301^{\star * *}$ & $2676^{\star * *}$ & 1302 & $3332^{\star * *}$ & $10972^{\star * *}$ \\
\hline gyrB & $3041^{\star * *}$ & $2641^{* * *}$ & $1511^{\star *}$ & 2911 & $10451^{* * *}$ \\
\hline Concatenated-ML & 2639 & $2548^{\star * *}$ & 1339 & 2932 & 9756 \\
\hline Concatenated-NJ & 2652 & $2526^{\star * *}$ & 1356 & 2960 & 9782 \\
\hline Concatenated-MrBayes & 2639 & $2538^{* * *}$ & 1337 & 2947 & 9751 \\
\hline
\end{tabular}




\section{RESULTS}

\section{Pathogenicity tests}

All pathotype A strains of pv. citri produced erumpent, callus-like lesions a week after inoculation, irrespective of the assayed host species. Pathotype $\mathrm{A}^{*}$ and $\mathrm{A}^{\mathrm{w}}$ strains produced erumpent, callus-like lesions on Mexican lime, Tahiti lime and alemow a week after inoculation, but not on grapefruit or sweet orange leaves. Very small, blister-like lesions were observed for some strains, sometimes in an irreproducible way, on the latter two citrus species. Detached Mexican lime leaves inoculated with $X$. citri pv. aurantifolii strains showed erumpent, callus-like lesions similar to those caused by pathotype $A, A^{\star}$ and $A^{w}$ strains. No lesions were recorded on leaves of other Citrus species inoculated with strains of this pathovar. Strains of X. campestris pv. bilvae did not cause canker-like symptoms, but produced extensive water-soaked lesions on Mexican lime leaves. Mean population densities 1 month after inoculation from these lesions ranged from $1 \times 10^{7}$ to $2 \times 10^{7}$ c.f.u. per lesion, typical of a compatible interaction. Necrotic lesions were observed on inoculated grapefruit and sweet orange leaves. Such reactions were regarded as incompatible interactions, given that mean population densities recovered from such lesions 1 month after inoculation were $\leqslant 2 \times 10^{2}$ c.f.u. per lesion. Differential pathogenicity among strains of $X$. campestris pv. bilvae was recorded on alemow. Small but consistently developing water-soaked lesions were observed for strain NCPPB 3213 (mean population size $2 \times 10^{6}$ c.f.u. per lesion) but not for strain NCPPB 1759 (mean population density $5 \times 10^{3}$ c.f.u. per lesion).

When bacterial multiplication was assayed over time, population densities of three pathotype $\mathrm{A}^{\star}$ strains (JK2-13, JK143-12 and JS751) were not different from those of pathotype A strains on alemow at 35 days p.i. Population densities recorded from lesions on alemow for strains CFBP 2911 and X2003-01029G at 35 days p.i. were significantly lower (by less than 0.8 log unit) than from other assayed strains. Population densities recorded from 20 to 35 days p.i. on grapefruit for all pathotype $A^{\star} / A^{w}$ strains were significantly lower than those recorded for pathotype A strains. One pathotype $A^{*}$ strain (JS551) from Iran produced small, blister-like lesions on grapefruit. $X$. citri pv. citri population densities in blister-like lesions recorded 7 to 35 days p.i. were approximately $1 \times 10^{5}$ c.f.u. per lesion, two log units lower than those recorded from canker-like lesions. Population densities for other pathotype $A^{*} / A^{w}$ strains on grapefruit were lower by three to four log units than those recorded for pathotype A strains.

\section{PCR assay}

Amplicons of the expected size were obtained with all X. citri pv. citri strains after the second round of PCR. However, no amplification product was visible after the first round of PCR with six pathotype $\mathrm{A}^{\mathrm{w}}$ strains from Florida and one pathotype $A^{*}$ strain from India (NCPPB 3608). The nucleotide sequences of the amplicon produced after the second round of PCR for strains X2003-01035G (pathotype $\mathrm{A}^{\mathrm{w}}$ ) and NCPPB 3608 (pathotype $\mathrm{A}^{\star}$ ) were fully identical (over $233 \mathrm{bp}$ ) to that of the target sequence (GenBank accession numbers AE008924.1 and AE008925.1).

\section{AFLP analysis}

Cluster analysis, based on 1314 AFLP fragments, placed most Xanthomonas genospecies in distinct lineages, supported by high bootstrap values $(>80 \%)$ (Fig. 1). Strains identified as pathovars of $X$. axonopodis sensu Vauterin et al. (1995) were distributed in six clusters, corresponding to the subgroups 9.1 to 9.6 sensu Rademaker et al. (2005). All subgroups except subgroup 9.6 were supported by bootstrap values above $80 \%$. Strains of pathovars citri and aurantifolii clustered within $X$. citri sensu Ah-You et al. (2009) (synonyms X. axonopodis subgroups 9.5 and 9.6), which is consistent with earlier studies. Strains that caused citrus canker on a narrow host range (pathotype $\mathrm{A}^{*}$ and $\mathrm{A}^{\mathrm{w}}$ strains) were most closely related to $X$. citri pv. citri strains with a wide host range (pathotype A): strains from the three pathotypes formed a group, which was quite distinct from other $X$. citri pathovars and supported by a strong bootstrap value (Fig. 1). Within-group EGD values ranged from 0.0010 to 0.0161 . Pathotype $A^{\mathrm{w}}$ strains were most closely related to a pathotype $A^{*}$ strain originating from India (NCPPB 3608), with an EGD of 0.0038. Pathotype $A^{*}$ (including $\mathrm{A}^{\mathrm{w}}$ strains; $n=38$ ) was found to be more diverse than pathotype A $(n=73)$, with median EGD values of 0.00802 and 0.00276 , respectively. EGD values between the type strain of $X$. citri and strains of $X$. citri pv. aurantifolii ranged from 0.0598 to 0.0693 .

When compared to all type strains of Xanthomonas, strains of $X$. campestris pv. bilvae were most closely related to the $X$. citri genospecies, with EGD values ranging from 0.0354 to 0.0372 . Their relatedness to the $X$. citri pv. citri strain collection studied here ranged from 0.0322 to 0.0512 .

\section{MLSA analysis}

Analysed sequence lengths ranged from $389 \mathrm{bp}$ (efp) to $773 \mathrm{bp}$ ( $g y r B)$, leading to a total of $2671 \mathrm{bp}$ for the four regions sequenced (Table 2). The number of alleles ranged from 30 (efp) to 42 ( $g y r B)$ (Table 2), with a mean of 36.8 alleles per locus. The $\mathrm{G}+\mathrm{C}$ content for all loci ranged from 63.1 to $64.6 \mathrm{~mol} \%$. The nucleotide diversity per site ranged from $0.0228(e f p)$ to $0.0315(g y r B)$. Nucleotide transitions exceeded transversions. All genes showed a mean $\mathrm{Ka} / \mathrm{Ks}<<1$, indicating that they were subject to stabilizing selection, conforming to the general requirements of MLSA. Stabilizing selection was further suggested by Tajima's D values for all genes (Table 2). No recombination event involving strains of $X$. citri was detected. Recombination was detected for Xanthomonas euvesicatoria for a part of the atpD gene (Supplementary Fig. S1). The detected recombination resulted in a distorted representation of $X$. axonopodis 


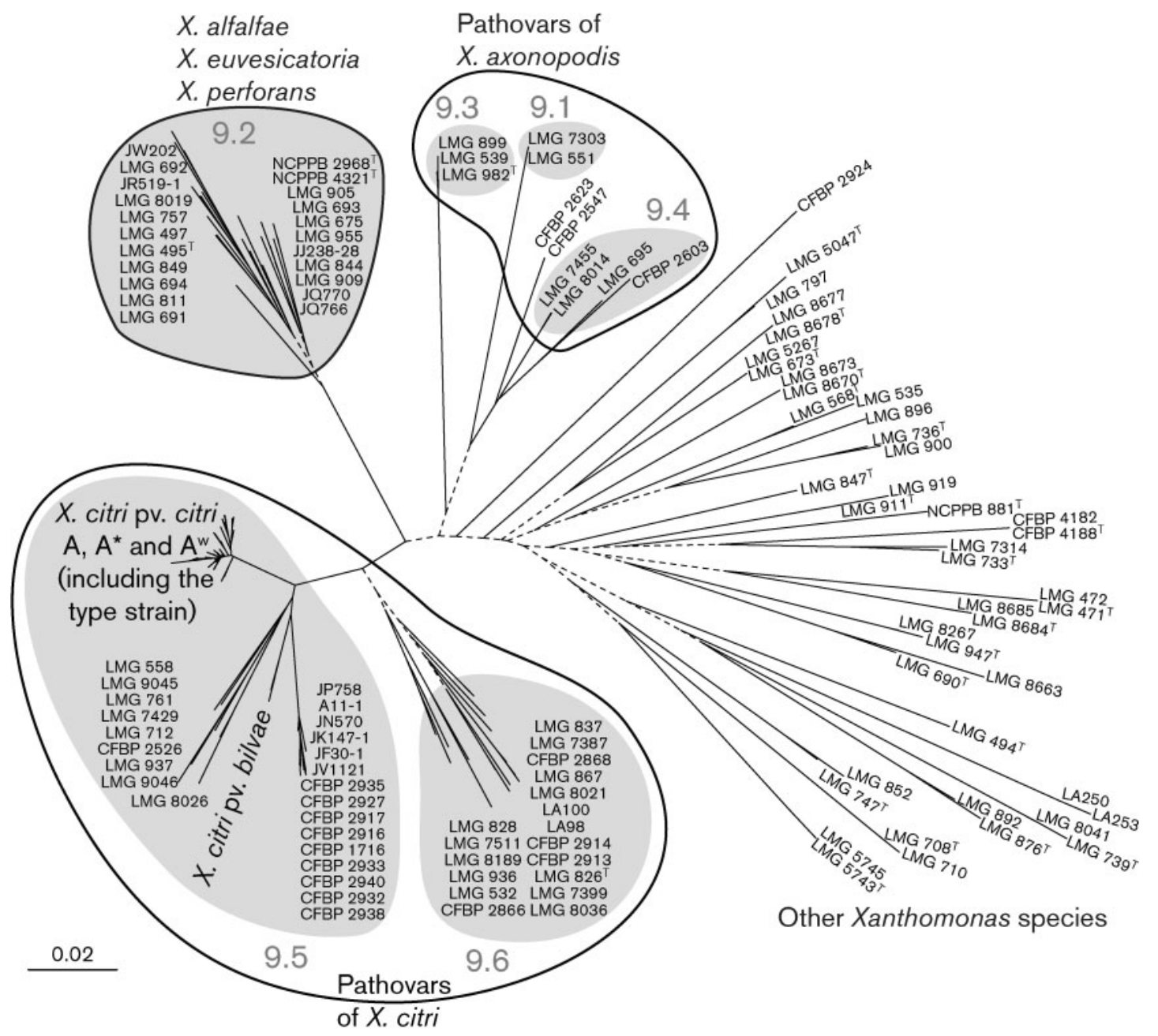

Fig. 1. Neighbour-joining tree derived from EGD values (Mougel et al., 2002; Portier et al., 2006) showing the relationships between $X$. citri and other Xanthomonas genospecies based on 1314 AFLP markers. Branches with bootstrap values lower than $80 \%$ are represented by dotted lines.

subgroup 9.2 sensu Rademaker et al. (2005), notably increasing the branch length of $X$. euvesicatoria on the tree derived from concatenated sequence data (Fig. 2).

The phylogenetic tree for each locus consistently clustered strains of X. axonopodis sensu Vauterin et al. (1995) according to Rademaker's subgroups (Supplementary Figs S1-S4). However, subgroups 9.1 and 9.4 did not appear as robust groups on trees based on efp or gyrB. Likelihoods for a given gene computed using the $\mathrm{S}-\mathrm{H}$ test were statistically different from those computed for the three other loci (Table 1). Most often, likelihoods computed from a single locus were congruent with that derived from concatenated sequence data, with the exception of $d n a K$ with all trees inferred from the concatenated datasets. All pathotype $\mathrm{A}, \mathrm{A}^{*}$ and $\mathrm{A}^{\mathrm{w}}$ strains of $X$. citri pv. citri as well as $X$. campestris pv. bilvae (NCPPB 3213 and NCPPB 1759 ) consistently clustered within the $X$. citri genospecies, regardless of the gene under analysis. No poly- morphic site was found at the four examined loci between pathotype $A^{*}$ and $A^{w}$ strains. Pathotype $A^{\star} / A^{w}$ strains were most closely related to pathotype A strains. Three sequence types (ST) were identified within $X$. citri pv. citri. All pathotype $A^{\star} / A^{w}$ were assigned to $S T 1$, whereas all but one pathotype A strains were assigned to ST2. The two groups could be distinguished on the basis of four synonymous mutations in the atpD sequence (one in the first codon position and three in the third codon position), corresponding to a synonymous nucleotide variation of $0.59 \%$. However, the molecular clock hypothesis was rejected for atpD (at the third codon position), precluding calculation of age estimates between pathotypes. So far, only strains NCPPB 3562 and LD7-1 (from India and Mali, respectively) were classified as ST3, for which a single synonymous mutation (at the third codon position) was identified in $d n a K$. ST3 differed from ST1 and ST2 by a synonymous nucleotide variation of 0.74 and $0.15 \%$, respectively. 
Table 2. Sequence variations for four housekeeping genes

\begin{tabular}{|c|c|c|c|c|}
\hline Gene & gyrB & $\operatorname{dnaK}$ & efp & $\operatorname{atpD}$ \\
\hline Length (bp) & 773 & 762 & 389 & 747 \\
\hline Position in strain $306(\mathrm{Mb})$ & 0.0 & 1.8 & 2.8 & 4.3 \\
\hline $\mathrm{Ts} / \mathrm{Tv}^{*}$ & $3.532(0.857)$ & $2.893(0.999)$ & $1.256(0.512)$ & $1.715(0.636)$ \\
\hline Mean nucleotide identity (minimum) & 0.968 & 0.969 & 0.977 & 0.976 \\
\hline $\mathrm{Ka} \dagger$ & $0.0014(0.0028)$ & $0.0016(0.0015)$ & $0.0037(0.0046)$ & $0.0054(0.0051)$ \\
\hline $\mathrm{Ka} / \mathrm{Ks} \dagger$ & $0.0106(0.0103)$ & $0.0115(0.0397)$ & $0.0374(0.0598)$ & $0.0544(0.0428)$ \\
\hline Alleles $(n)$ & 42 & 39 & 30 & 36 \\
\hline $\begin{array}{l}\text { Variable sites (sites leading to synonymous } \\
\text { mutations) }(n)\end{array}$ & 146 & 115 & 60 & 129 \\
\hline Nucleotide diversity per site & 0.0315 & 0.0313 & 0.0228 & 0.0271 \\
\hline Tajima’s D $\ddagger$ & -1.1512 & -0.5289 & -1.4114 & -1.1874 \\
\hline
\end{tabular}

${ }^{*}$ Transition/transversion ratio determined using Kimura's two-parameter method (Kimura, 1980). Values in parentheses are standard deviations. $\dagger$ Synonymous and non-synonymous substitution rates determined using the method of Nei \& Gojobori (1986). Values in parentheses are standard deviations.

$\$$ Not significant $(P>0.10)$.

Phylogenetic trees were inferred from concatenated sequences using the NJ, ML and Bayesian methods based on evolution model GTR $+\Gamma+\mathrm{I}$ (Fig. 2 and Supplementary Figs S5 and S6). The average branch length produced from the Bayesian analysis after estimating the lambda parameter from the ML tree $(l a m b d a=293)$ was similar to those calculated for the NJ and ML trees, at 0.0031, 0.0015 and 0.0023 , respectively. All methods produced congruent trees (Table 1), as indicated using $\mathrm{S}-\mathrm{H}$ tests of alternative tree topologies. As shown with the ML tree (Fig. 2), major branches were supported by high bootstrap values $(>80 \%)$ and strain grouping matched the $X$. axonopodis subgroups proposed by Rademaker et al. (2005). Pathotype A, A* and $\mathrm{A}^{\mathrm{w}}$ strains causing citrus canker always grouped within $X$. citri and were highly related, irrespective of the phylogenetic inference method employed. All strains of $X$. citri pv. citri were most distantly related to $X$. citri pv. aurantifolii, which was consistent with earlier studies (Cubero \& Graham, 2002; Rademaker et al., 2005). Pathotype $\mathrm{A}^{\star}$ and $\mathrm{A}^{\mathrm{w}}$ strains shared identical sequence types and were distinguishable from pathotype A strains. X. campestris pv. bilvae strains clustered within the $X$. citri genospecies. They were most closely related to $X$. citri pv. glycines (LMG 712).

Distances between pathotype $A$ and pathotype $A^{\star} / A^{w}$ strains calculated with the GTR $+\Gamma+$ I model, based on concatenated sequences, ranged from 0.0015 to 0.0019 , while genetic distances from other pathovars in the same genospecies ranged from 0.0015 to 0.0235 and were greater than 0.0273 with subgroups 9.1 to 9.4 of $X$. axonopodis. The genetic distance between the type strain of $X$. citri and strains of $X$. campestris pv. bilvae was 0.0030 . The genetic distance between the type strain of $X$. citri and strains of $X$. citri pv. aurantifolii ranged from 0.0211 to 0.0235 . Correlation values $(\mathrm{w}=0.861, P<0.001)$ obtained from the Mantel test suggested that data derived from AFLP and MLSA using concatenated sequences were highly congruent.

\section{DISCUSSION}

The pathovar classification of bacterial plant pathogens (Dye et al., 1980; Young et al., 1992) is an infrasubspecific classification, applied by reference to host range or capacity to cause distinctive symptoms. Pathogenicity tests are, therefore, an essential part of this classification. However, an increasing number of contributions have demonstrated that classifications based on genetic fingerprinting or sequencing methods, which correlate well with DNADNA hybridization data (e.g. AFLP, rep-PCR and/or MLSA), also often provide an adequate reflection of the pathovar classification in the genus Xanthomonas (Ah-You et al., 2007, 2009; Louws et al., 1999; Rademaker et al., 2000, 2005, 2006; Scortichini \& Rossi, 2003). This indicates that pathovars are distinct genetic entities, even at the genome level. This differentiation can be explained by the separation of ecological niches induced by host specialization, which has led to different selective pressures and to de facto environmental isolation. It also suggests that the host specialization processes outlined at the pathovar level occurred a long time ago. However, the date of such separation in the course of evolution has not been documented.

Host specialization associated with subtle genetic polymorphism has sometimes been referred to as pathotypes, an infrapathovar classification (Civerolo \& Fan, 1982; Verdier et al., 1998). Our study aimed primarily at characterizing phylogenetic relationships between pathotypes of $X$. citri pv. citri and the genetically related pathovar 


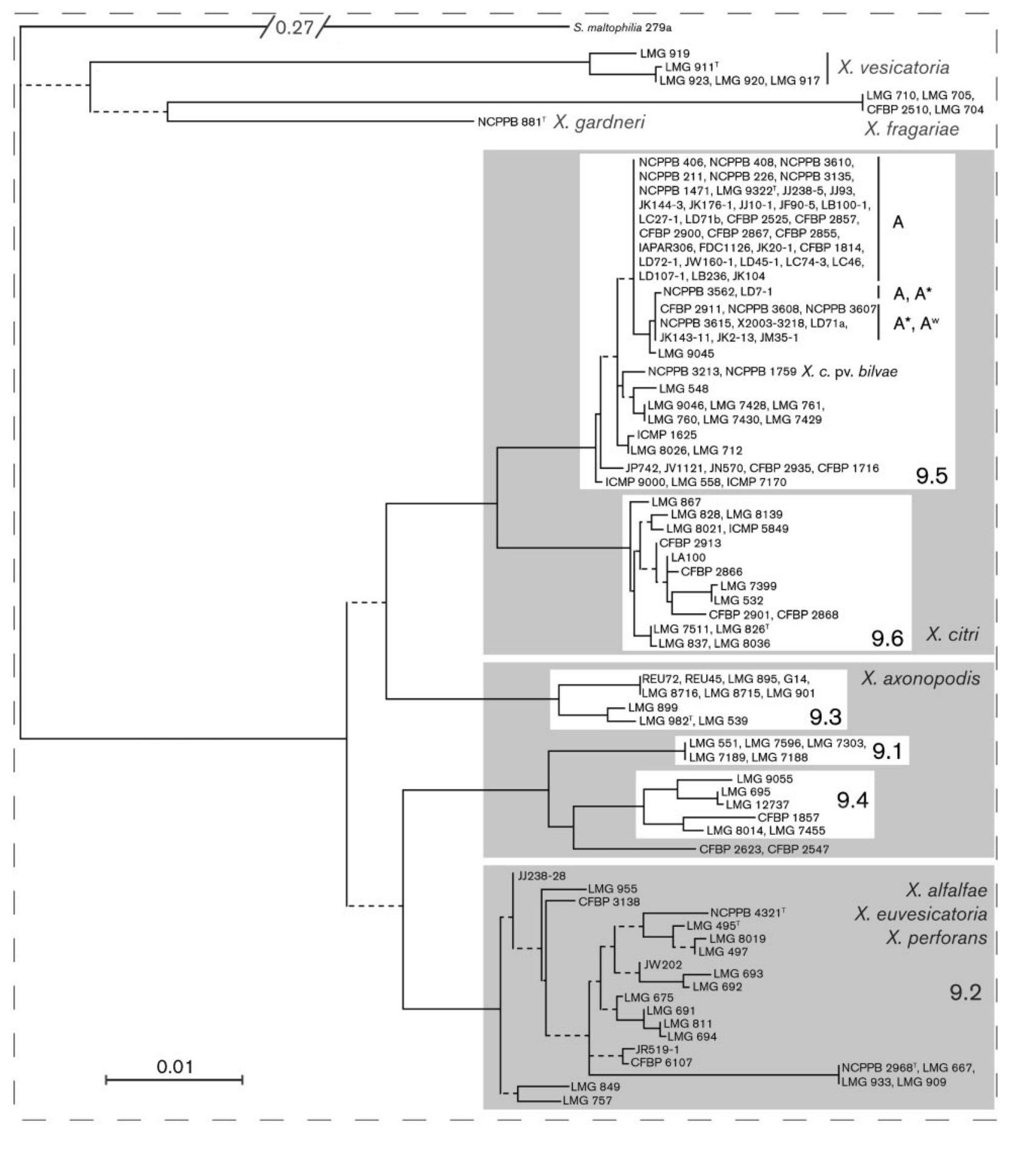

Fig. 2. Maximum-likelihood tree derived from the GTR $+\Gamma+I$ model, based on concatenated atp $D$, dnaK, efp and gyrB partial sequences, showing the relationships between strains of $X$. citri and some other Xanthomonas genospecies, including $X$. axonopodis subgroups (Rademaker et al., 2000, 2005). Branches with bootstrap values lower than $80 \%$ are represented by dotted lines.

bilvae. To achieve this, we used AFLP and MLSA, techniques that have been given emphasis for species delineation in bacterial taxonomy (Stackebrandt et al., 2002).
In this study, we show that bacterial strains that were isolated from members of two rutaceous host genera (Aegle and Feronia) in India, currently classified as X. campestris, are closely related to the type strain of $X$. citri but distantly 
related to the type strain of $X$. campestris. Based on AFLP and MLSA, these strains were more closely related to $X$. citri pv. citri than to $X$. citri pv. aurantifolii. Genetic distances between $X$. citri and $X$. campestris pv. bilvae derived from these two techniques corresponded to $\Delta T_{\mathrm{m}}$ values $<2.0{ }^{\circ} \mathrm{C}$ (Ah-You et al., 2009). Therefore, these strains should be reclassified within the $X$. citri genospecies as $X$. citri pv. bilvae. Pathogenicity tests showed that strains of $X$. citri pv. bilvae produced extensive lesions on attached Mexican lime leaves and multiplied markedly within the mesophyll, therefore confirming an earlier report from India (Patel et al., 1953). The fact that the pathovars citri and bilvae are commonly pathogenic to Aegle marmelos, Feronia limonia and Citrus aurantifolia, but have clearly distinct symptomatologies, justifies their classification as two different pathovars of X. citri (Dye et al., 1980). This finding indicates that xanthomonads that produce bacterial spot-like lesions on rutaceous host species are not restricted to $X$. axonopodis subgroup 9.2 (synonym Xanthomonas alfalfae), as previously thought (Rademaker et al., 2005; Schaad et al., 2005).

Interestingly, genetic distances derived from AFLP and MLSA were highly correlated. These techniques show that all strains that cause canker-like lesions on citrus, classified as pathovars aurantifolii and citri (Gabriel et al., 1989), are members of the X. citri genospecies sensu Ah-You et al. (2009). All three pathotypes described within pathovar citri (Sun et al., 2004; Vernière et al., 1998) were closely related genetically, confirming previous DNA-DNA hybridizations performed on a limited number of strains (Sun et al., 2004). Whatever the technique used, all strains of $X$. citri pv. citri with a narrow host range (pathotypes $\mathrm{A}^{*}$ and $\mathrm{A}^{\mathrm{w}}$ ) were more closely related to strains with a wide host range (pathotype A) than to any other pathovar within X. citri. MLSA showed that all strains belonging to pathotypes $A^{*}$ or $\mathrm{A}^{\mathrm{w}}$ were identical, suggesting that they shared a fairly recent common ancestor. These strains could also not be distinguished on the basis of pathogenicity tests. They shared a similar host range, restricted to Mexican lime, Tahiti lime and alemow, with no differences in symptomatology. Some pathotype $\mathrm{A}^{*}$ strains caused small, blister-like reactions on sweet orange and grapefruit, but these reactions were not observed reproducibly for some strains, making this criterion impossible to use for pathotype classification. The weaker in planta multiplication of strains producing blister-like reactions suggests that such reactions should not be considered typical compatible interactions, consistent with earlier reports (Ah-You et al., 2007; Egel et al., 1991). Our results on the host range of pathotype $\mathrm{A}^{\star}$ and $\mathrm{A}^{\mathrm{w}}$ strains disagree with those reported by Sun et al. (2004). These authors similarly scored disease reactions caused by pathotype $A^{\star}$ strains on Mexican lime and sweet orange. Sweet orange was described as the differential host species for distinguishing pathotypes $A^{*}$ and $\mathrm{A}^{\mathrm{w}}$ (Sun et al., 2004). In the present study, we show that sweet orange leaves inoculated with pathotype $A^{*}$ strains show no or very limited blister-like reactions but no canker-like reactions. Consequently, our data showed no clear difference in the host ranges of pathotype $A^{*}$ and $A^{\mathrm{w}}$ strains, consistent with the results of Brunings \& Gabriel (2003).

Furthermore, one feature of pathotype $\mathrm{A}^{\mathrm{w}}$ strains that was considered to be unique was their lack of amplicon production from primers specific to X. citri pv. citri (Sun et al., 2004). In this study, we showed that this feature was shared with some pathotype $A^{*}$ strains originating from India. All the strains for which no amplicon was visible using these primers did produce a visible amplicon with internal primers. The DNA sequence of a $233 \mathrm{bp}$ amplicon portion obtained from a pathotype $\mathrm{A}^{\mathrm{w}}$ strain was fully identical to that of the target fragment, suggesting that the lack of PCR amplification with external primers may be due to polymorphisms at the binding sites of external primers. We conclude that pathotype $A^{\mathrm{w}}$ is a junior synonym of pathotype $A^{\star}$, a group of strains with a wide genetic diversity, and that the latter designation should be preferred. An analysis of the genetic diversity of 234 strains of $X$. citri pv. citri originating from Asia, the likely centre of origin of the pathogen, by AFLP and insertion sequence ligation-mediated PCR targeting three insertion sequences suggested that pathotype $\mathrm{A}^{*}$ (including $\mathrm{A}^{\mathrm{w}}$ strains) is a group of strains that shows a wider genetic diversity than pathotype A, suggesting a longer evolutionary history of pathotype $A^{\star}$ strains (Bui Thi Ngoc et al., 2009).

\section{ACKNOWLEDGEMENTS}

We thank J. Young and E. L. Civerolo for helpful discussion and C. Boyer, K. Vital and V. Ledoux for their technical assistance. The European Union (FEOGA and FEDER), Conseil Régional de La Réunion and CIRAD provided financial support.

\section{REFERENCES}

Ah-You, N., Gagnevin, L., Chiroleu, F., Jouen, E., Neto, J. R. \& Pruvost, O. (2007). Pathological variations within Xanthomonas campestris pv. mangiferaeindicae support its separation into three distinct pathovars that can be distinguished by Amplified Fragment Length Polymorphism. Phytopathology 97, 1568-1577.

Ah-You, N., Gagnevin, L., Grimont, P. A. D., Brisse, S., Nesme, X., Chiroleu, F., Bui Thi Ngoc, L., Jouen, E., Lefeuvre, P. \& other authors (2009). Polyphasic characterization of xanthomonads pathogenic to Anacardiaceae and their relatedness to different Xanthomonas species. Int J Syst Evol Microbiol 59, 306-318.

Balestra, G. M., Sechler, A., Schuenzel, E. \& Schaad, N. W. (2008). First report of citrus canker caused by Xanthomonas citri in Somalia. Plant Dis 92, 981.

Boni, M. F., Posada, D. \& Feldman, M. W. (2007). An exact nonparametric method for inferring mosaic structure in sequence triplets. Genetics 176, 1035-1047.

Boudon, S., Manceau, C. \& Notteghem, J. L. (2005). Structure and origin of Xanthomonas arboricola pv. pruni populations causing bacterial spot of stone fruit trees in Western Europe. Phytopathology 95, 1081-1088.

Brown, J. M., Hedtke, S. M., Lemmon, A. R. \& Lemmon, E. M. (2009). When trees grow too long: investigating the causes of highly 
inaccurate Bayesian branch-length estimates. Syst Biol doi:10.1093/ sysbio/syp081

Brunings, A. M. \& Gabriel, D. W. (2003). Xanthomonas citri: breaking the surface. Mol Plant Pathol 4, 141-157.

Bui Thi Ngoc, L., Vernière, C., Pruvost, O., Kositcharoenkul, N. \& Phawichit, S. (2007). First report in Thailand of Xanthomonas axonopodis pv. citri- $\mathrm{A}^{\star}$ causing citrus canker on lime. Plant Dis 91, 771.

Bui Thi Ngoc, L., Vernière, C., Pruvost, O., So, T. \& Johnson, G. I. (2008). First report of Xanthomonas axonopodis pv. citri-A* causing citrus canker on lime in Cambodia. Plant Dis 92, 1588.

Bui Thi Ngoc, L., Vernière, C., Jarne, P., Brisse, S., Guérin, F., Boutry, S., Gagnevin, L. \& Pruvost, O. (2009). From local surveys to global surveillance: three high throughput genotyping methods for the epidemiological monitoring of Xanthomonas citri pv. citri pathotypes. Appl Environ Microbiol 75, 1173-1184.

Chelo, I. M., Zé-Zé, L. \& Tenreiro, R. (2007). Congruence of evolutionary relationships inside the Leuconostoc-OenococcusWeissella clade assessed by phylogenetic analysis of the 16S rRNA gene, dnaA, gyrB, rpoC and dnaK. Int J Syst Evol Microbiol 57, 276-286.

Civerolo, E. L. (1984). Bacterial canker disease of citrus. J Rio Grande Val Hortic Soc 37, 127-145.

Civerolo, E. L. \& Fan, F. (1982). Xanthomonas campestris pv. citri detection and identification by enzyme-linked immunosorbent assay. Plant Dis 66, 231-236.

Cubero, J. \& Graham, J. H. (2002). Genetic relationship among worldwide strains of Xanthomonas causing canker in citrus species and design of new primers for their identification by PCR. Appl Environ Microbiol 68, 1257-1264.

Da Silva, A. C., Ferro, J. A., Reinach, F. C., Farah, C. S., Furlan, L. R., Quaggio, R. B., Monteiro-Vitorello, C. B., Van Sluys, M. A., Almeida, N. F. \& other authors (2002). Comparison of the genomes of two Xanthomonas pathogens with differing host specificities. Nature 417, 459-463.

Dowson, W. J. (1939). On the systematic position and generic names of the Gram negative bacterial plant pathogens. Zentralbl Bakteriol Parasitenkd Infeckt 2, 177-193.

Dye, D. W., Bradbury, J. F., Goto, M., Hayward, A. C., Lelliott, R. A. \& Schroth, M. N. (1980). International standards for naming pathovars of phytopathogenic bacteria and a list of pathovar names and pathotype strains. Rev Plant Pathol 59, 153-168.

Egel, D. S., Graham, J. H. \& Riley, T. D. (1991). Population dynamics of Xanthomonas campestris differing in aggressiveness on Swingle citrumelo and grapefruit. Phytopathology 81, 666-671.

Fawcett, H. S. \& Jenkins, A. E. (1933). Records of citrus canker from herbarium specimens of the genus Citrus in England and the United States. Phytopathology 23, 820-824.

Gabriel, D. W., Kingsley, M. T., Hunter, J. E. \& Gottwald, T. (1989). Reinstatement of Xanthomonas citri (ex Hasse) and X. phaseoli (ex Smith) to species and reclassification of all $X$. campestris pv. citri strains. Int J Syst Bacteriol 39, 14-22.

Gevers, D., Cohan, F. M., Lawrence, J. G., Spratt, B. G., Coenye, T., Feil, E. J., Stackebrandt, E., Van de Peer, Y., Vandamme, P. \& other authors (2005). Re-evaluating prokaryotic species. Nat Rev Microbiol 3, 733-739.

Gibbs, M. J., Armstrong, J. S. \& Gibbs, A. J. (2000). Sister-Scanning: a Monte Carlo procedure for assessing signals in recombinant sequences. Bioinformatics 16, 573-582.

Gottwald, T. R., Graham, J. H. \& Schubert, T. S. (2002). Citrus canker: the pathogen and its impact. In Plant Health Progress. http:// www.plantmanagementnetwork.org/php/elements/sum.aspx?id=2191 \&photo $=412$
Guindon, S. \& Gascuel, O. (2003). A simple, fast, and accurate algorithm to estimate large phylogenies by maximum likelihood. Syst Biol 52, 696-704.

Hanage, W. P., Fraser, C. \& Spratt, B. G. (2005a). Fuzzy species among recombinogenic bacteria. BMC Biol 3, 6.

Hanage, W. P., Kaijalainen, T., Herva, E., Saukkoriipi, A., Syrjanen, R. \& Spratt, B. G. (2005b). Using multilocus sequence data to define the pneumococcus. J Bacteriol 187, 6223-6230.

Hartung, J. S. \& Civerolo, E. L. (1989). Restriction fragment length polymorphism distinguishes Xanthomonas campestris strains isolated from Florida citrus nurseries from X. c. pv. citri. Phytopathology 79, 793-799.

Hartung, J. S., Daniel, J. F. \& Pruvost, O. P. (1993). Detection of Xanthomonas campestris pv. citri by the polymerase chain reaction method. Appl Environ Microbiol 59, 1143-1148.

Hartung, J. S., Pruvost, O. P., Villemot, I. \& Alvarez, A. (1996). Rapid and sensitive colorimetric detection of Xanthomonas axonopodis pv. citri by immunocapture and a nested-polymerase chain reaction assay. Phytopathology 86, 95-101.

Janssen, P., Coopman, R., Huys, G., Swings, J., Bleeker, M., Vos, P., Zabeau, M. \& Kersters, K. (1996). Evaluation of the DNA fingerprinting method AFLP as a new tool in bacterial taxonomy. Microbiology 142, 1881-1893.

Kimura, M. (1980). A simple method for estimating evolutionary rates of base substitutions through comparative studies of nucleotide sequences. J Mol Evol 16, 111-120.

Louws, F. J., Rademaker, J. L. W. \& De Bruijn, F. J. (1999). The three Ds of PCR-based genomic analysis of phytobacteria: diversity, detection, and disease diagnosis. Annu Rev Phytopathol 37, 81-125.

Mantel, N. (1967). The detection of disease clustering and a generalized regression approach. Cancer Res 27, 209-220.

Martens, M., Delaere, M., Coopman, R., De Vos, P., Gillis, M. \& Willems, A. (2007). Multilocus sequence analysis of Ensifer and related taxa. Int J Syst Evol Microbiol 57, 489-503.

Martin, D. \& Rybicki, E. (2000). RDP: detection of recombination amongst aligned sequences. Bioinformatics 16, 562-563.

Martin, D. P., Posada, D., Crandall, K. A. \& Williamson, C. (2005a). A modified bootscan algorithm for automated identification of recombinant sequences and recombination breakpoints. AIDS Res Hum Retroviruses 21, 98-102.

Martin, D. P., Williamson, C. \& Posada, D. (2005b). RDP2: recombination detection and analysis from sequence alignments. Bioinformatics 21, 260-262.

Maynard-Smith, J. (1992). Analyzing the mosaic structure of genes. J Mol Evol 34, 126-129.

Mougel, C., Thioulouse, J., Perrière, G. \& Nesme, X. (2002). A mathematical method for determining genome divergence and species delineation using AFLP. Int J Syst Evol Microbiol 52, 573-586.

Nei, M. \& Gojobori, T. (1986). Simple methods for estimating the numbers of synonymous and nonsynonymous nucleotide substitutions. Mol Biol Evol 3, 418-426.

Padidam, M., Sawyer, S. \& Fauquet, C. M. (1999). Possible emergence of new geminiviruses by frequent recombination. Virology 265, 218-225.

Paradis, E., Claude, J. \& Strimmer, K. (2004). APE: analyses of phylogenetics and evolution in R language. Bioinformatics 20, 289-290.

Patel, M. K., Allayyanavaramath, S. B. \& Kulkarni, Y. S. (1953). Bacterial shot-hole and fruit canker of Aegle marmelos Correa. Curr Sci 22, 216-217.

Peakall, R. \& Smouse, P. E. (2006). GENALEX 6: genetic analysis in Excel. Population genetic software for teaching and research. Mol Ecol Notes 6, 288-295. 
Portier, P., Fischer-Le Saux, M., Mougel, C., Lerondelle, C., Chapulliot, D., Thioulouse, J. \& Nesme, X. (2006). Identification of genomic species in Agrobacterium biovar 1 by AFLP genomic markers. Appl Environ Microbiol 72, 7123-7131.

Posada, D. (2006). ModelTest Server: a web-based tool for the statistical selection of models of nucleotide substitution online. Nucleic Acids Res 34, W700-W703.

Posada, D. \& Buckley, T. R. (2004). Model selection and model averaging in phylogenetics: advantages of Akaike information criterion and Bayesian approaches over likelihood ratio tests. Syst Biol 53, 793-808.

Posada, D. \& Crandall, K. A. (2001). Evaluation of methods for detecting recombination from DNA sequences: computer simulations. Proc Natl Acad Sci U S A 98, 13757-13762.

Pruvost, O., Hartung, J. S., Civerolo, E. L., Dubois, C. \& Perrier, X. (1992). Plasmid DNA fingerprints distinguish pathotypes of Xanthomonas campestris pv. citri, the causal agent of citrus bacterial canker disease. Phytopathology 82, 485-490.

Pruvost, O., Roumagnac, P., Gaube, C., Chiroleu, F. \& Gagnevin, L. (2005). New media for the semi-selective isolation and enumeration of Xanthomonas campestris pv. mangiferaeindicae, the causal agent of mango bacterial black spot. J Appl Microbiol 99, 803-815.

Rademaker, J. L. W., Hoste, B., Louws, F. J., Kersters, K., Swings, J., Vauterin, L., Vauterin, P. \& De Bruijn, F. J. (2000). Comparison of AFLP and rep-PCR genomic fingerprinting with DNA-DNA homology studies: Xanthomonas as a model system. Int J Syst Evol Microbiol 50, 665-677.

Rademaker, J. L. W., Louws, F. J., Schultz, M. H., Rossbach, U., Vauterin, L., Swings, J. \& De Bruijn, F. J. (2005). A comprehensive species to strain taxonomic framework for Xanthomonas. Phytopathology 95, 1098-1111.

Rademaker, J. L. W., Norman, D. J., Forster, R. L., Louws, F. J., Schultz, A. H. \& Bruijn, F. J. (2006). Classification and identification of Xanthomonas translucens isolates, including those pathogenic to ornamental asparagus. Phytopathology 96, 876-884.

Richter, D., Postic, D., Sertour, N., Livey, I., Matuschka, F. R. \& Baranton, G. (2006). Delineation of Borrelia burgdorferi sensu lato species by multilocus sequence analysis and confirmation of the delineation of Borrelia spielmanii sp. nov. Int J Syst Evol Microbiol 56, 873-881.

Ronquist, F. \& Huelsenbeck, J. P. (2003). MrBayes 3: Bayesian phylogenetic inference under mixed models. Bioinformatics 19, 1572-1574.

Roumagnac, P., Gagnevin, L., Gardan, L., Sutra, L., Manceau, C., Dickstein, E. R., Jones, J. B., Rott, P. \& Pruvost, O. (2004). Polyphasic characterization of xanthomonads isolated from onion, garlic and Welsh onion (Allium spp.) and their relatedness to different Xanthomonas species. Int J Syst Evol Microbiol 54, 15-24.

Rozas, J., Sanchez-Del Barrio, J. C., Messeguer, X. \& Rozas, R. (2003). DnaSP, DNA polymorphism analyses by the coalescent and other methods. Bioinformatics 19, 2496-2497.

Schaad, N. W., Postnikova, E., Lacy, G. H., Sechler, A., Agarkova, I., Stromberg, P. E., Stromberg, V. K. \& Vidaver, A. K. (2005). Reclassification of Xanthomonas campestris pv. citri (ex Hasse 1915) Dye 1978 forms A, B/C/D, and E as X. smithii subsp. citri (ex Hasse) sp. nov. nom. rev. comb. nov., $X$. fuscans subsp. aurantifolii (ex Gabriel 1989) sp. nov. nom. rev. comb. nov., and X. alfalfae subsp. citrumelo (ex Riker and Jones) Gabriel et al., 1989 sp. nov. nom. rev. comb. nov.; X. campestris pv. malvacearum (ex Smith 1901) Dye 1978 as $X$. smithii subsp. smithii nov. comb. nov. nom. nov.; X. campestris pv. alfalfae (ex Riker and Jones, 1935) Dye 1978 as X. alfalfae subsp. alfalfae (ex Riker et al., 1935) sp. nov. nom. rev.; and "var. fuscans" of X. campestris pv. phaseoli (ex Smith, 1987) Dye 1978 as X. fuscans subsp. fuscans sp. nov. Syst Appl Microbiol 28, 494-518.
Schaad, N. W., Postnikova, E., Lacy, G. H., Sechler, A., Agarkova, I., Stromberg, P. E., Stromberg, V. K. \& Vidaver, A. K. (2006). Emended classification of xanthomonad pathogens on citrus. Syst Appl Microbiol 29, 690-695.

Schmidt, H. A., Strimmer, K., Vingron, M. \& Von Haeseler, A. (2002). TREE-PUZZLE: maximum likelihood phylogenetic analysis using quartets and parallel computing. Bioinformatics 18, 502-504.

Scortichini, M. \& Rossi, M. P. (2003). Genetic diversity of Xanthomonas arboricola pv. fragariae strains and comparison with some other $X$. arboricola pathovars using repetitive PCR genomic fingerprinting. J Phytopathol 151, 113-119.

Shimodaira, M. \& Hasegawa, M. (1999). Multiple comparisons of log-likelihoods with applications to phylogenetic inference. Mol Biol Evol 16, 1114-1116.

Stackebrandt, E., Frederiksen, W., Garrity, G. M., Grimont, P. A. D., Kämpfer, P., Maiden, M. C. J., Nesme, X., Rosselló-Mora, R., Swings, J. \& other authors (2002). Report of the ad hoc committee for the re-evaluation of the species definition in bacteriology. Int $J$ Syst Evol Microbiol 52, 1043-1047.

Stolp, H., Starr, M. P. \& Baigent, N. L. (1965). Problems in speciation of phytopathogenic pseudomonads and xanthomonads. Annu Rev Phytopathol 3, 231-265.

Sun, X. A., Stall, R. E., Jones, J. B., Cubero, J., Gottwald, T. R., Graham, J. H., Dixon, W. N., Schubert, T. S., Chaloux, P. H. \& other authors (2004). Detection and characterization of a new strain of citrus canker bacteria from Key Mexican lime and Alemow in South Florida. Plant Dis 88, 1179-1188.

Tajima, F. (1989). Statistical method for testing the neutral mutation hypothesis by DNA polymorphism. Genetics 123, 585-595.

Tamura, K., Dudley, J., Nei, M. \& Kumar, S. (2007). MEGA4: molecular evolutionary genetics analysis (MEGA) software version 4.0. Mol Biol Evol 24, 1596-1599.

Thompson, J. D., Gibson, T. J., Plewniak, F., Jeanmougin, F. \& Higgins, D. G. (1997). The CLUSTAL_X windows interface: flexible strategies for multiple sequence alignment aided by quality analysis tools. Nucleic Acids Res 25, 4876-4882.

Traoré, Y. N., Bui Thi Ngoc, L., Vernière, C. \& Pruvost, O. (2008). First report of Xanthomonas citri pv. citri causing citrus canker in Mali. Plant Dis 92, 977.

Vauterin, L., Hoste, B., Kersters, K. \& Swings, J. (1995). Reclassification of Xanthomonas. Int J Syst Bacteriol 45, 472-489.

Verdier, V., Restrepo, S., Mosquera, G., Duque, M. C., Gerstl, A. \& Laberry, R. (1998). Genetic and pathogenic variation of Xanthomonas axonopodis pv. manihotis in Venezuela. Plant Pathol 47, 601-608.

Vernière, C., Pruvost, O., Civerolo, E. L., Gambin, O., JacquemoudCollet, J. P. \& Luisetti, J. (1993). Evaluation of the Biolog substrate utilization system to identify and assess metabolic variation among strains of Xanthomonas campestris pv. citri. Appl Environ Microbiol 59, 243-249.

Vernière, C., Hartung, J. S., Pruvost, O. P., Civerolo, E. L., Alvarez, A. M., Maestri, P. \& Luisetti, J. (1998). Characterization of phenotypically distinct strains of Xanthomonas axonopodis pv. citri from Southwest Asia. Eur J Plant Pathol 104, 477-487.

Vos, P., Hogers, R., Bleeker, M., Reijans, M., van de Lee, T., Hornes, M., Frijters, A., Pot, J., Peleman, J. \& other authors (1995). AFLP: a new technique for DNA fingerprinting. Nucleic Acids Res 23, 4407-4414.

Young, J. M., Takikawa, Y., Gardan, L. \& Stead, D. E. (1992). Changing concepts in the taxonomy of plant pathogenic bacteria. Annu Rev Phytopathol 30, 67-105. 